\title{
MOTYWY I UWARUNKOWANIA CHIŃSKICH BEZPOŚREDNICH INWESTYCJI ZAGRANICZNYCH W AFRYCE
}

Afryka jest niezwykle bogata w zasoby, a mimo to w Afryce Subsaharyjskiej wiele osób wciąż nie ma dostępu do czystej wody, urządzeń sanitarnych oraz elektryczności. Struktura sektorowa produkcji oraz towarowa eksportu krajów afrykańskich jest związana z chronicznym niedoborem kapitału i inwestycji oraz implikuje dużą wrażliwość tych państw na podaż kapitału zagranicznego. Rosnące zaangażowanie Chin w Afryce Subsaharyjskiej nadal budzi zainteresowanie badaczy oraz opinii publicznej. Celem niniejszego artykułu jest przedstawienie motywów oraz uwarunkowań chińskich bezpośrednich inwestycji zagranicznych (BIZ) w Afryce w odniesieniu do najważniejszych teorii ich lokowania. W analizie wykorzystano dane za lata 2008-20181. Punktem wyjścia do rozważań jest hipoteza, że głównym motywem chińskich BIZ w Afryce jest poszukiwanie zasobów. W pracy badawczej zostały wykorzystane metody opisowe, analityczne oraz studia literaturowe.

\section{Motywy napływu bezpośrednich inwestycji zagranicznych - ujęcie teoretyczne}

Przy inwestycjach bezpośrednich inwestorzy zagraniczni kierują się przede wszystkim motywem uzyskania kontroli nad krajowymi obiektami majątku. Dąża oni do zajęcia pozycji współwłaścicieli. Ostatecznym celem jest tutaj również (jak w przypadku inwestycji portfelowych) uzyskanie zysku z kapitału. Potwierdzają to zarówno teoria ekonomii, jak i liczne studia empiryczne. Mimo że osiąnięcie zysku jest główną determinantą procesu przepływów bezpośrednich inwestycji zagranicznych, to zagraniczni inwestorzy podkreślają także inne motywy realizowania takich

ORCID: 0000-0002-3740-7360, DOI: 10.4467/23538724GS.20.025.12143

1 W momencie złożenia artykułu do druku pełne dane za 2019 rok nie były jeszcze dostępne. 
inwestycji (głównie czynniki popytowo-rynkowe, restrykcje handlowe, uregulowania prawne, koszty pracy i transportu $)^{2}$.

Ważnym celem przedsiębiorstw dokonujących bezpośrednich inwestycji jest obniżanie kosztów produkcji. Chodzi o to, by przez przeniesienie produkcji z zagranicy do kraju czerpać korzyści z różnicy kosztów. Ponadto polityczno-gospodarcze instytucje danego kraju w celu zachęcenia do BIZ mogą oferować inwestorom zagranicznym pewne przywileje (np. zyski wolne od podatków), tworzyć sprzyjające warunki ekonomiczne w postaci stref uprzywilejowanych, gwarancji kredytowych czy gwarancji rządowych. Obniżenie kosztów poprzez przeniesienie produkcji z zagranicy do kraju goszczącego inwestycje może być także uwarunkowane niedostatecznym dostosowaniem kursu wymiany i zróżnicowaniem siły walut poszczególnych krajów (teoria obszarów walutowych R.Z. Alibera). Dla inwestora z kraju o silnej walucie zakup akcji przedsiębiorstwa z kraju o słabej walucie może być korzystny, gdyż akcje te powinny być dla niego względnie tańsze. Przy ich wycenie uwzględnia się oczekiwaną stopę dewaluacji, a także niepewność związaną z rzeczywistym kształtowaniem się kursów wymiany walut. Inwestor powinien zatem otrzymać premię za ryzyko. Ponadto w przypadku dyskontowania strumienia dochodów filii należącej do zagranicznego inwestora z kraju o mocnej walucie stosowana jest wyższa stopa kapitalizacji w porównaniu do wskaźnika w analogicznym przedsiębiorstwie lokalnym. Biorąc pod uwagę ten czynnik, bardziej opłacalne są BIZ dokonywane w kraju o słabej walucie niż te w kraju o walucie silnej ${ }^{3}$.

Do innych istotnych motywów inwestycji zagranicznych zalicza się także takie czynniki, jak chęć wykorzystania pozycji monopolistycznej swojego przedsiębiorstwa (teoria monopolistycznej przewagi S. Hymera i Ch. Kindlebergera), internacjonalizacja gospodarki (teoria internacjonalizacji J.C. McManusa) oraz minimalizacja ryzyka poprzez geograficzną i gałęziową dywersyfikację działalności gospodarczej (teoria portfela inwestycyjnego H.M. Markowitza). Niezwykle ważnym motywem jest również komplementarność krajów w zakresie wyposażenia w kapitał, co pociąga za sobą zróżnicowanie stopy zysku z kapitału między krajami, a także dostępność taniej, wykwalifikowanej siły roboczej4.

W dyskusji nad inwestycjami zagranicznymi podnosi się także negatywne konsekwencje oddziaływania kapitału obcego. Jedną z nich jest dążenie do

\footnotetext{
2 R. Schumann, Międyynarodowe inwestycje bespośrednie: pojecie, podstany wyznaczajace inwestycje, tendencje rozwojowe, seria: Prace Naukowe Akademii Ekonomicznej we Wrocławiu, nr 760, Wrocław 1997, s. 311- 328; też: R.J. Carbaugh, International Economics, 14 ${ }^{\text {th }}$ ed., South-Western Cengage Learning, Mason, OH 2013, s. 298-300.

3 Należy podkreślić, że teoria Alibera nie do końca sprawdza się w praktyce, gdyż większość BIZ jest dokonywana pomiędzy krajami o silnej walucie. Por. J. Rymarczyk, Biznes miedzyynarodowy, Warszawa 2012, s. 156, 157.

4 J. Rymarczyk, Internacjonalizacja przedsiębiorstwa, Warszawa 1996, s. 32-39; idem, Internacjonalizacja i globalizacja przedsiebiorstwa, Warszawa 2004.
} 
maksymalizacji zysków w kraju przyjmującym oraz wiążąca się z tym możliwość powstania deficytu bilansu płatniczego poprzez transfer zysków i kapitałów na rzecz jednostki macierzystej. Innym skutkiem może być ograniczenie suwerenności i kontrola gospodarki kraju inwestowania lub też narzucenie własnego modelu gospodarowania. BIZ mogą również stanowić zagrożenie dla początkujących gałęzi przemysłu kraju przyjmującego kapitał poprzez m.in. stosowanie międzynarodowych cen transferowych, zawyżanie/zaniżanie cen, zawyżanie/zaniżanie odsetek czy należności licencyjnych.

Napływ kapitału zagranicznego równy deficytowi obrotów bieżących lub wyższy od niego umożliwia podniesienie tempa wzrostu gospodarki, tym większe, im więcej tego kapitału zainwestowano $\mathrm{w}$ działalność produkcyjna. Zatem transfer kapitału w postaci inwestycji zagranicznych nie tylko zwiększa rezerwy walutowe kraju, ale także pozytywnie wpływa na jego wzrost gospodarczy. Z tego względu ważna jest również struktura kapitału zagranicznego z punktu widzenia horyzontu czasowego i charakteru inwestowania: nowe inwestycje bezpośrednie, inwestycje portfelowe na rozpoczęcie działalności, wykup spółek, znaczne rozszerzenie kapitału, fuzje etc. Przyrost rezerw zagranicznych nie jest celem z punktu widzenia przyśpieszenia wzrostu, choć stanowi zabezpieczenie bilansu płatniczego. Duży napływ kapitału zagranicznego $i$ wzrost rezerw walutowych wpływają natomiast na politykę finansową banku centralnego i kurs waluty krajowej, powodując presję na wzrost podaży pieniądza krajowego i aprecjację waluty krajowej ${ }^{5}$.

Motywy dokonywania ekspansji zagranicznej można klasyfikować na wiele sposobów. Najczęściej wyróżnia się cztery poniższe

- czynniki rynkowe, takie jak: wielkość i chłonność rynku, utrzymanie pozycji rynkowej lub jej rozszerzenie, zwiększenie eksportu firmy, utrzymanie bliskich kontaktów z klientami, baza eksportowa na sąsiednie rynki;

- czynniki kosztowe, takie jak niższe koszty pracy, surowców oraz transportu, system rządowych bodźców finansowych, niższe podatki oraz generalnie bardziej korzystny poziom kosztów;

- czynniki związane z klimatem inwestycyjnym (polityczne), takie jak: stosunek do inwestycji zagranicznych, stabilność polityczna, ograniczenia własnościowe, regulacje wymiany walut oraz stabilność systemu walutowego, przyjazne stosunki z krajem przyjmującym;

- zaopatrzeniowe, czyli bliskość źródeł zaopatrzenia, dostępność czynnika pracy, surowców, kapitału i technologii, dostęp do nowoczesnej wiedzy.

W gospodarce rynkowej podstawowym kryterium lokalizacji działalności gospodarczej jest maksymalizacja zysku, jaką zakłada inwestor. Musi on wziąć pod uwage

5 Z. Sadowski, Kapitat zagranic₹ny w Polsce. Warunki dziatania, Warszawa 1999, s. 15.

6 E. Oziewicz, Korporacje transnarodowe jako sita napedowa procesu globalizacji [w:] Globalizacja i regionalizacja w gospodarce światowej, red R. Orłowska, K. Żołądkiewicz, Warszawa 2012, s. 45. 
nie tylko analizę ekonomiczną opłacalności inwestycji, ale także wiele czynników składających się na poziom ryzyka i atrakcyjności danego rynku zagranicznego.

Najpopularniejszy i najczęściej cytowany podział motywów inwestycyjnych stworzył J.H. Dunning. Uważa on, że przedsiębiorstwo decyduje się na zagraniczne inwestycje bezpośrednie tylko wtedy, kiedy jego działalność gospodarcza za granicą będzie bardziej zyskowna niż we własnym kraju. Dunning wyróżnia cztery typy inwestycji ${ }^{7}$ :

- inwestycje, których celem jest poszukiwanie/zdobywanie zasobów w kraju goszczącym (Resource-seeking Foreign Direct Investements);

- inwestycje nastawione na poszukiwanie rynków zbytu (Market-seeking Foreign Direct Investements);

- inwestycje zorientowane na podwyższenie efektywności (Efficiency-seeking Foreign Direct Investements);

- inwestycje związane z poszukiwaniem/zdobywaniem aktywów strategicznych (Strategic assets-seeking Foreign Direct Investements).

Inwestycje bezpośrednie, których celem jest poszukiwanie zasobów w kraju goszczącym, wiążą się zazwyczaj z chęcią osiagnnięcia określonych przewag kosztowych, wynikających z dostępu do tańszych i/lub wyższej jakości zasobów obecnych w gospodarce przyjmujacej kapitał. Wśród inwestorów ukierunkowanych na zasoby można wyróżnić trzy podstawowe typy przedsiębiorstw ${ }^{8}$. Pierwszy obejmuje inwestorów wykorzystujących istniejące w kraju goszczącym różnego typu zasoby surowcowe (np. rudy metali, ropa naftowa, gaz ziemny, produkty rolne) z uwagi na ich jakość, cenę lub dostępność dla zagranicznych inwestorów. Celem nadrzędnym tego typu BIZ jest nie tylko minimalizacja kosztów, ale także zabezpieczenie źródeł dostaw tych zasobów. Warto bowiem dodać, że większość korporacji podejmujacych inwestycje bezpośrednie typu natural resources-seeking eksportuje ostatecznie swoje produkty do krajów macierzystych. Jest to główny typ BIZ występujący w Afryce. Należy dodać, że do kategorii przedsiębiorstw poszukujących zasobów naturalnych zaliczane są korporacje działające m.in. w branży paliwowej, drzewnej czy wydobywczej, natomiast jeżeli przedsiębiorstwo poszukuje zasobów ludzkich, to miejscem lokalizacji działalności jest gospodarka, w której istnieje tania siła robocza, odznaczająca się jednocześnie odpowiednią wydajnością. Inwestycje tego typu podejmują zarówno korporacje transnarodowe z rynków wschodzących (emerging markets), jak i z krajów rozwiniętych. W Afryce obserwuje się inwestycje zarówno z Chin, Indii, jak i Stanów Zjednoczonych czy państw Unii Europejskiej.

Drugi typ inwestycji podejmowany jest przez korporacje poszukujące na zagranicznych rynkach taniej, zwykle niewykwalifikowanej lub średnio wykwalifikowanej

7 J.H. Dunning, S.M Lundan, Multinational Enterprises and the Global Economy, Cheltenham 2008, s. 79-115.

8 Ibidem, s. 69. 
siły roboczej. BIZ tego typu pochodzą na ogół z krajów rozwiniętych, gdzie koszty pracy sa relatywnie wysokie. Filie zagraniczne sa zakładane przede wszystkim w krajach rozwijających się i stanowią źródło produktów skierowanych głównie na eksport.

Trzeci rodzaj obejmuje inwestorów szukających możliwości przejęcia zasobów niematerialnych, np. rozwiązań technologicznych, marketingowych czy organizacyjnych. Zarówno według Dunninga, jak i Vernona decyzja dotycząca miejsca podjęcia przez inwestora zagranicznego działalności gospodarczej, zwłaszcza o charakterze produkcyjnym, poza krajem macierzystym zależy od kosztów czynników produkcji, jakości tych czynników (w szczególności od ofert wykwalifikowanej siły roboczej) oraz szeroko rozumianej infrastruktury. Kraje rozwijające się są interesujące jako miejsca lokalizacji procesów produkcyjnych produktów normalizowanych, które w znacznej części mogą być produkowane przez niewykwalifikowanych pracowników ${ }^{9}$. Celem inwestycji typu efficiency-seeking jest racjonalizacja podjętych wcześniej inwestycji typu resource-seeking oraz market-seeking w taki sposób, aby firma mogła efektywniej zarządzać rozproszonymi geograficznie spółkami. Z reguły podnoszenie efektywności jako motyw BIZ dotyczy dużych, doświadczonych oraz jednocześnie posiadających ugruntowaną pozycję korporacji, które chcą skorzystać z istniejących na danym rynku goszczącym możliwości, wykorzystując w sposób pełniejszy własne przewagi ${ }^{10}$.

Czwarty typ stanowią inwestycje nastawione na poszukiwanie zasobów strategicznych. Cechą wyróżniającą je jest chęć utrzymania lub też wzmocnienia pozycji konkurencyjnej na rynku globalnym poprzez przejmowanie aktywów zagranicznych przedsiębiorstw. Celem przedsiębiorstw nie jest zatem wyłącznie uzyskiwanie dostępu do marketingowego know-how czy sposobów redukcji kosztów, lecz przede wszystkim nabywanie fizycznych aktywów przedsiębiorstw oraz wiedzy i kompetencji pracowników (buman competences) ${ }^{11}$. Określona przez J.H. Dunninga klasyfikacja motywów ma charakter raczej ogólny i dość syntetyczny. Rzeczywiste działania zagranicznych inwestorów są zazwyczaj na tyle złożone, że identyfikacja poszczególnych motywów jest trudna, a konkretne decyzje stanowią raczej wypadkową kilku z nich. Co więcej, struktura motywów, jakimi inwestor kieruje się w swej działalności, zmienia się w czasie. Na przykład przewartościowaniu może ulec znaczenie rynku krajowego bądź rynków eksportowych w strategii działania przedsiębiorców.

\footnotetext{
9 W. Karaszewski, Bezpośrednie inwestycje zagraniczne. Polska na tle świata, Toruń 2004, s. 53.

10 J.H. Dunning, S.M. Lundan, Multinational Enterprises..., s. 72.

11 J. Clegg, H. Voss, Chinese Overseas Direct Investment in the European Union, Europe China Research and Advice Network, http://www.chathamhouse.org/ (dostęp: 3.04.2020).
} 


\section{Napływ bezpośrednich inwestycji zagranicznych do Afryki- ujęcie statystyczne}

Rekordowy pod względem napływu BIZ do Afryki był rok 2008. Inwestycje osiągnęły wówczas poziom 72,2 mld USD. Można to tłumaczyć gwałtownym wzrostem cen surowców, szczególnie ropy naftowej, który spowodował nagłe zwiększenie inwestycji w produkty podstawowe. Światowy kryzys finansowy miał podwójnie negatywny wpływ na sytuację krajów afrykańskich. Ucierpieli inwestorzy, którzy ograniczyli zakres działania. Równolegle kryzys zmniejszył popyt na afrykańskie surowce. To spowodowało obniżenie inwestycji kapitałowych w sektorach i krajach, w których historycznie skupiała się największa część inwestycji zagranicznych. W latach 2009-2018 napływ BIZ do Afryki wynosił przeciętnie 40-50 mld USD rocznie. W 2018 r. przepływy BIZ do Afryki przeciwstawiły się globalnej tendencji spadkowej BIZ na świecie i wyniosły 45,9 mld USD (rys. 1), jednakże jest to znacząco mniej niż w $2008 \mathrm{r}$. Rosnące ceny i popyt na niektóre towary doprowadziły w 2018 r. do trwałych inwestycji w poszukiwanie zasobów. Kilka gospodarek, takich jak Kenia, Maroko i Tunezja, odnotowało wówczas znaczny wzrost napływających inwestycji. Bezpośrednie inwestycje zagraniczne w Republice Południowej Afryki w 2018 r. pierwszy raz od kilku lat zanotowały wzrost. Spadł natomiast poziom inwestycji napływających do dotychczasowych liderów w przyjmowaniu BIZ: Nigerii, Egiptu i Etiopii ${ }^{12}$.

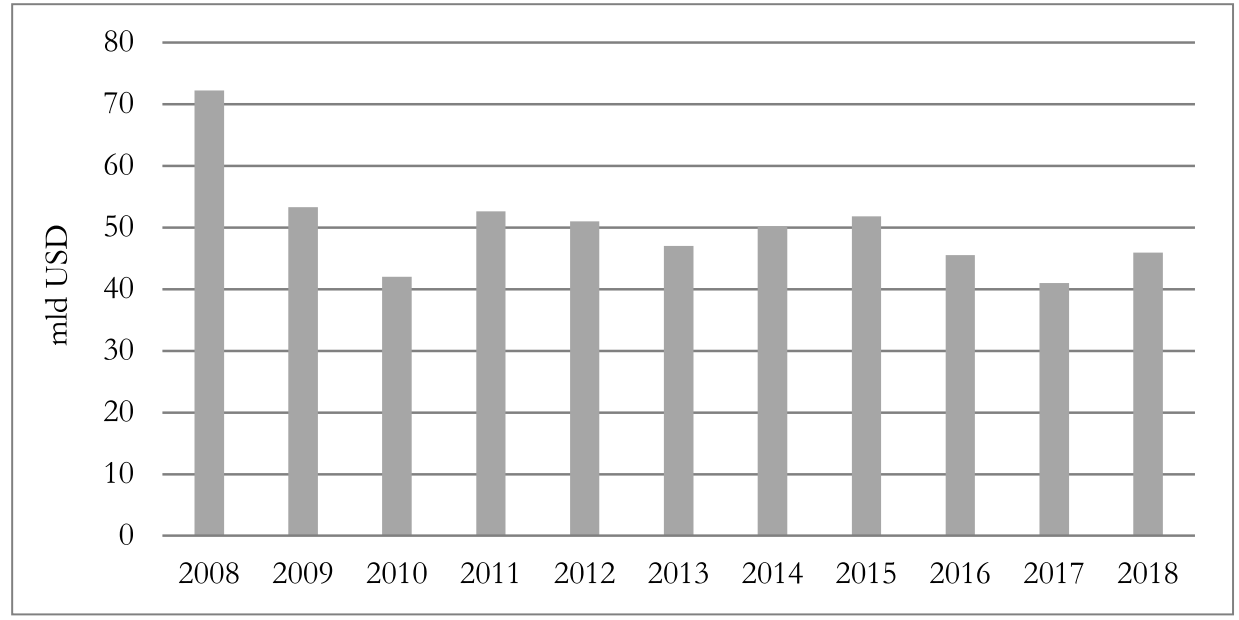

Rys. 1. Napływ BIZ do Afryki w latach 2008-2018

Źródło: Opracowanie własne na podstawie danych UNCTAD, www.unctad.org (dostęp: 10.05.2020).

12 World Investment Report 2019, UNCTAD, Geneva 2019, s. 36. 
Napływ bezpośrednich inwestycji zagranicznych do Afryki Północnej w 2018 r. wyniósł 14 mld USD, co stanowi przyrost o 7\% w porównaniu do 2017 r., głównie za sprawą Egiptu, który pozostał największym odbiorcą BIZ w Afryce i przyciagnął 6,8 mld USD spośród tych inwestycji. Bezpośrednie inwestycje zagraniczne w Afryce Zachodniej spadły w 2018 r. do poziomu 9,6 mld USD, co jest najniższym rezultatem od 2006 r., głównie ze względu na znaczny spadek BIZ w Nigerii. Przepływy BIZ do Afryki Wschodniej w 2018 r. były w dużej mierze takie same jak rok wcześniej i wyniosły 9 mld USD, mimo że Etiopia odnotowała osiemnastoprocentowy spadek r/r do 3,3 mld USD. W 2018 r. do Kenii napłynęło 1,6 mld USD w postaci bezpośrednich inwestycji zagranicznych (wzrost o 27\% w porównaniu do 2017 r.), a co ważne, pojawiły się duże projekty infrastrukturalne, mogące przyczynić się do trwałego rozwoju regionu. Przepływy BIZ do Afryki Środkowej w 2018 r. pozostały na podobnym poziomie co rok wcześniej i wyniosły 8,8 mld USD. W 2018 r. Kongo odnotowało wpływy BIZ w wysokości 4,3 mld USD, głównie na poszukiwanie i wydobycie ropy naftowej. Dalsze inwestycje w minerały, zwłaszcza kobalt, stanowiły podstawę przepływów BIZ do Demokratycznej Republiki Konga, które w 2018 r. osiagnęły poziom 1,5 mld USD (wzrost o 11\% r/r). BIZ w Afryce Południowej gwałtownie wzrosły ( $z$-0,9 mld USD w 2017 r. do 4,2 mld USD w 2018 r.), głównie z powodu ożywienia gospodarczego w RPA (wzrost z 2 mld USD w 2017 r. do 5,3 mld USD w 2018 r., w tym inwestycje w motoryzację i energię odnawialna). Mozambik w 2018 r. otrzymał również wyższe niż przed rokiem wpływy w wysokości 2,7 mld USD. Było to jednak w dużej mierze spowodowane transferami wewnątrzfirmowymi z przedsiębiorstw już utworzonych w tym kraju, głównie w celu poszukiwania ropy i gazu ${ }^{13}$. Rok 2018 był dla Afryki korzystny pod względem napływu BIZ i polepszyła się jej sytuacja na tle gospodarki światowej. Co do prognoz na przyszłość, otwarte pozostaje pytanie, jak spowolnienie gospodarcze związane z pandemią koronawirusa wpłynie na napływ inwestycji do Afryki oraz czy znów zaobserwujemy ich spadek w dobie nadciagającego kryzysu, analogicznie do sytuacji z 2009 r.

Krajami, które w całym analizowanym okresie (lata 2008-2018) przyciagnęły najwięcej BIZ w Afryce, były RPA (jako najbardziej rozwinięte państwo kontynentu), Egipt oraz producenci ropy naftowej (przede wszystkim Nigeria i Angola). Globalny kryzys finansowy, który rozpoczął się w 2008 r., doprowadził do spowolnienia napływu BIZ do Afryki i w latach 2009-2018 nie udało się osiagnąć tak gwałtownego wzrostu, jak przed kryzysem.

W ostatnich dwóch dekadach nastapił znaczny napływ kapitału do krajów rozwijających się, a po 2008 r. ich udział w globalnych przepływach kapitałowych istotnie się zwiększył. Niestety, udział Afryki jest niewielki. W 2018 r. do Afryki napłynęły bezpośrednie inwestycje zagraniczne o wartości 45,6 mld USD. Pod względem

13 Ibidem, s. 37. 
udziału w całkowitej wielkości przepływów kapitałowych kontynent ten partycypuje w 3,56\% światowego napływu i 1\% odpływu. Większość kapitału napłynęła tutaj w ciagu ostatnich 10 lat, a była kierowana głównie do krajów bogatych w surowce, w celu ich eksploatacji. Jest to szczególnie widoczne przy analizie BIZ w ujęciu regionalnym, gdzie zdecydowanie wyróżniają się regiony, których kraje mają charakter głównie surowcowy. Zwracają uwagę znaczne fluktuacje w napływach kapitału, wynikające zarówno z wahań cen, jak i z sytuacji w gospodarce światowej ${ }^{14}$. Do Afryki napływają inwestycje przede wszystkim z Francji, Wielkiej Brytanii i Stanów Zjednoczonych.

Między 2013 a 2018 r. zanotowano duży przyrost inwestycji z Azji, głównie z Chin i Hongkongu oraz Holandii (tab. 1). W dobie światowej pandemii i nadchodzącej recesji gospodarczej Afryka bardziej niż wcześniej będzie potrzebować wsparcia z zewnątrz. Istnieje prawdopodobieństwo, że pograżone w kryzysie państwa Europy Zachodniej oraz Stany Zjednoczone będą musiały ograniczyć aktywność międzynarodową do niezbędnego minimum. W 2018 r. Chiny były piątym największym inwestorem w Afryce. Pandemia koronawirusa stanowi zagrożenie dla bezpieczeństwa ekonomicznego Afryki, co z perspektywy Chin może otworzyć możliwość dalszego wzmocnienia wpływów w regionie Afryki Subsaharyjskiej. Chińskie koncerny państwowe mogłyby wykorzystać powszechną zapaść do ekspansji w Afryce, Europie i Ameryce Północnej, aczkolwiek taki scenariusz wymagałby stabilnej sytuacji gospodarczej w Chinach. To wydaje się mało prawdopodobne, zważywszy na prognozy mówiące o recesji w Państwie Środka.

Tabela 1. Główne kraje pochodzenia BIZ w Afryce w 2013 i 2018 r. (mld USD)

\begin{tabular}{|l|c|c|}
\hline \multicolumn{1}{|c|}{ Kraj } & 2013 & $\mathbf{2 0 1 8}$ \\
\hline Francja & 64 & 64 \\
\hline Holandia & 20 & 63 \\
\hline Stany Zjednoczone & 61 & 60 \\
\hline Wielka Brytania & 60 & 46 \\
\hline Chiny & 26 & 43 \\
\hline Włochy & 19 & 28 \\
\hline RPA & 22 & 27 \\
\hline Singapur & 16 & 19 \\
\hline Hongkong & 9 & 16 \\
\hline Indie & 14 & 13 \\
\hline
\end{tabular}

Źródło: Opracowanie własne na podstawie: World Investment Report 2019, UNCTAD, Geneva 2019, s. 34.

14 T. Rynarzewski, K. Nawrot, K. Zajączkowski, E. Cieślik, Potencjał gospodarç̌y i możliwości rozwojowe Afryki, Warszawa 2017, s. 49. 
Oczekiwany wzrost gospodarczy, prognozowany na podstawie perspektywicznego wzrostu liczby ludności i dochodów w gospodarkach wschodzących, daje inwestorom możliwość osiagnięcia potencjalnie wysokich dochodów z inwestycji. Tezę tę potwierdza boom w zakresie napływu BIZ do światowej czołówki gospodarek wschodzących. Napływ BIZ do Brazylii, Rosji, Indii, Chin i Południowej Afryki wzrastał średnio o 28\% rocznie w latach 2000-2010. Potencjał rynku daje krajom rozwijającym się szansę na osiagnięcie w przyszłości dobrobytu ${ }^{15}$. Badania Instytutu McKinsey Global z 2012 r. pokazują, że zwłaszcza Afryka ma więcej szans na osiąganie większych zwrotów z inwestycji niż jakikolwiek inny rozwijający się region.

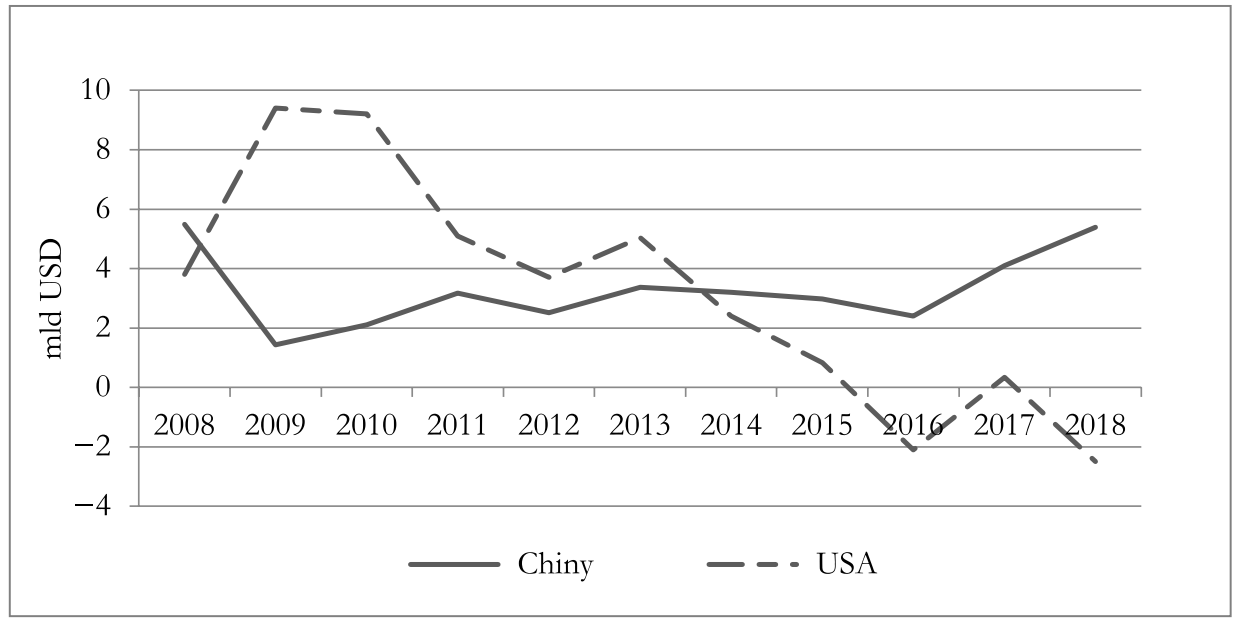

Rys. 2. Przepływy chińskich i amerykańskich BIZ do Afryki w latach 2008-2018

Źródło: Opracowanie własne na podstawie danych UNCTAD, www.unctad.org (dostęp: 19.04.2020).

Z punktu widzenia polityki gospodarczej realizowanej przez władze regionalne, odnoszącej się do oddziaływania na BIZ, należy wspomnieć, że motywy, jakimi kieruje się inwestor, nie muszą być zgodne z motywacją regionalnych władz. Przykładowo, z punktu widzenia regionu korzystne jest, aby napływające BIZ podejmowane były w sektorach nowoczesnych technologii, sprzyjały zmianie struktury gospodarki w stronę wysoce konkurencyjnych, proeksportowo zorientowanych branż produkcji, przy której rozwija się współpraca z lokalną sferą nauki i badań, a sama produkcja jest przyjazna dla środowiska. Inwestor natomiast może kierować się całkiem odmiennymi motywami. Jego zamiarem może być przeniesienie nie najnowszej technologii do regionu, w którym ze względu na niższą siłę nabywczą można jeszcze realizować strategię przedłużenia cyklu życia produktu. Inwestor może

15 International Business Research, vol. 4, no. 4, Canadian Center of Science and Education, October 2011, s. 255-257. 
być także zainteresowany po prostu przejęciem konkurencyjnego podmiotu w kraju goszczącym i docelowo wyeliminowaniem go z rynku ${ }^{16}$.

Nomathemba Mhlanga, który badał wskaźnik ryzyka politycznego w gospodarce goszczącej, uzyskał dość zaskakujące wyniki ${ }^{17}$. Według autora kraje o wyższym wskaźniku ryzyka przyciągają większą liczbę inwestorów. Rezultat ten może wynikać z tego, że do swoich badań N. Mhlanga wykorzystał dane z takich krajów, jak np. Angola, gdzie wskaźnik ryzyka jest wysoki, ale lokalizacja ta przyciaga inwestorów ze względu na znajdujące się tam zasoby naturalne, jak gaz ziemny czy ropa naftowa. Generalnie jednak, biorąc pod uwagę czynniki ryzyka dla inwestorów: poziom biurokracji, korupcję oraz ryzyko wywłaszczenia, okazuje się, że im korzystniejsze uwarunkowania instytucjonalne w danym kraju, tym większe prawdopodobieństwo pojawienia się zagranicznych korporacji na rynku.

Roczne przepływy chińskich bezpośrednich inwestycji zagranicznych do Afryki stale rosną od 2003 r. W latach 2003-2018 ich wartość wzrosła z 75 mln USD do 5,4 mld USD. Przepływy osiagnęły najwyższy poziom w 2008 r. w wysokości 5,5 mld USD z powodu zakupu 20\% akcji Standard Bank of South Africa przez Industrial and Commercial Bank of China (ICBC). Jak przedstawiono na rys. 2, chińskie przepływy BIZ do Afryki przewyższały przepływy z USA od 2014 r., ponieważ te ostatnie spadają nieprzerwanie od 2010 r. W 2018 r. najwięcej chińskich BIZ trafiło do Republiki Południowej Afryki, Demokratycznej Republiki Konga, Mozambiku, Zambii i Etiopii ${ }^{18}$.

Afryka jest kontynentem bogatym we wszelkiego rodzaju surowce mineralne, a Chiny są jednym z największych ich konsumentów. Zależność ta w istotny sposób warunkuje chińskie inwestycje w krajach afrykańskich. Rozmiar gospodarki Chin powoduje bowiem ogromne zapotrzebowanie na energię, co z kolei sprawia, są kraj ten obecnie jest jednym z głównych uczestników światowego systemu energetycznego. Zwiększony import surowców obserwowany w ostatnich latach oddziałuje zarówno na światowe ceny, jak i procesy zachodzące na rynkach gazu, węgla kamiennego oraz ropy naftowej. Sytuacja energetyczna Chin jest tym bardziej interesująca, że należą one do największych producentów wielu surowców na świecie ${ }^{19}$. Głównym celem działań Chińczyków jest budowa solidnych i stabilnych podstaw zamożności państwa. Aby to osiagnąć, muszą rozwiązać poważny problem zapewnienia dostaw surowców oraz rynków zbytu dla własnych produktów ${ }^{20}$.

16 S. Umiński, Handel zagraniczny jako płaszcryzna oddziatywania zmian w gospodarce globalnej na gospodarke regionu, Instytut Rozwoju, Working Papers no. 003/2013, s. 5.

17 N. Mhlanga, G. Blalock, R. Christy, Understanding foreign direct investment in the southern African development community: an analyst based on project-level data, „Agricultural Economics”, May-June 2010, vol. 41, s. 337-347.

18 China Africa Research Initiative, www.sais-cari.org (dostęp: 10.04.2020).

19 B. Skulska, Biznes międżnarodowy w regionie Azji i Pacyfiku, Torun 2009, s. 171.

20 Z. Bijian, China's "Peaceful Rise” to Great-Power Status, „Foreign Affairs” 2005, no. 10, s. 21. 
W koncepcji zintegrowanej wielkiej strategii umacnianie obecności Chin w Afryce zajmuje ważne miejsce, a ich polityka surowcowa i udzielana pomoc gospodarcza mają stać się skutecznym sposobem prowadzenia polityki zagranicznej i realizacji jej celów. BIZ z kapitałem chińskim w większości skierowane są w kierunku sektora przemysłu wydobywczego oraz budownictwa.

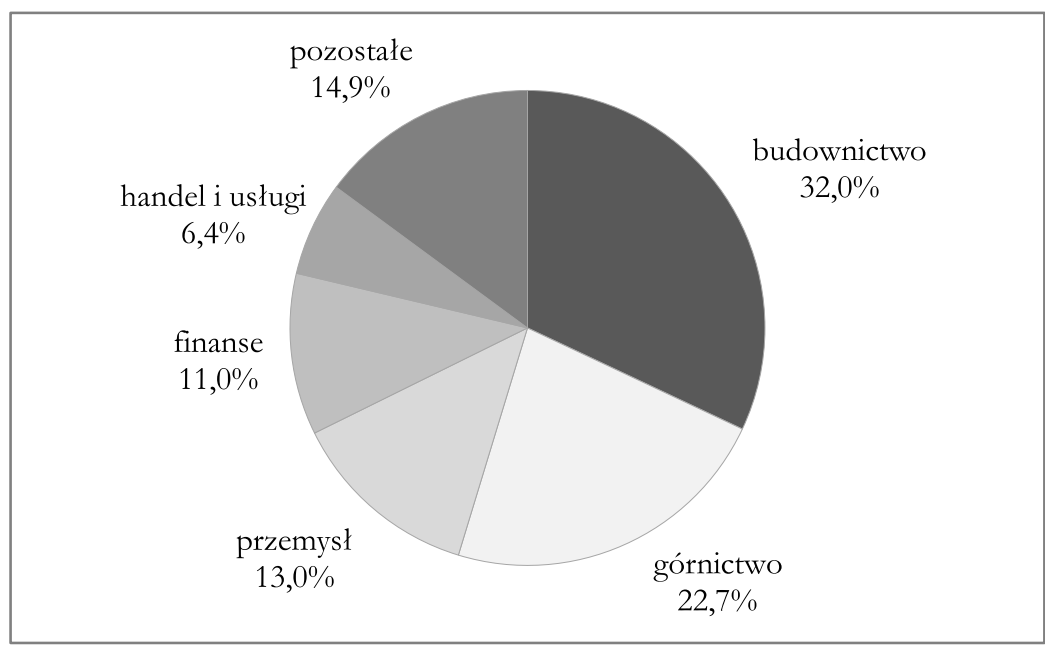

Rys. 3. Chińskie BIZ w Afryce według sektorów działalności w 2018 r.

Źródło: Opracowanie własne na podstawie: Statistical Bulletin of China’s Outward Foreign Direct Investment, http://fec.mofcom.gov.cn (dostęp: 19.04.2020).

W 2018 r. budownictwo i górnictwo stanowiło ponad 54\% chińskich BIZ w Afryce (rys. 3), co potwierdza tezę o strategii dostępu do surowców. Wychodzące BIZ z kapitałem chińskim zostały skoncentrowane również na trzech innych sektorach: budownictwie, branży produkcyjnej (przemyśle) i finansowej. W sumie te wymienione cztery sektory stanowią ok. $80 \%$ BIZ z kapitałem chińskim skierowanych na kontynent afrykański. Natomiast BIZ w usługach pozafinansowych oraz inwestycje w sektorze rolniczym według chińskich statystyk są nieznaczne, zwłaszcza w zakresie wykupu ziemi ${ }^{21}$.

Eksperci McKinsey zwracają uwagę, że oficjalne statystyki nie uwzględniają prawdziwej skali chińskiego zaangażowania. Koncentrują się one przede wszystkim na wielkich przedsięwzięciach infrastrukturalnych, jak np. uruchomionej kosztem 3,8 mld USD linii kolejowej z Nairobi do Mombasy w Kenii czy budowanej za ok. 1,7 mld USD hydroelektrowni Karuma w Ugandzie. Nie zawsze natomiast uwzględniają inwestycje i obecność w Afryce tysięcy chińskich firm, przede wszyst-

${ }^{21}$ E. Ambukita, Chińskie inwestycje w Afryce - szanse czy zagrożenie, „Zeszyty Naukowe Uniwersytetu Szczecińskiego” 2015, nr 855, s. 676. 
kim z sektora prywatnego, które w warunkach wolnego rynku na własną rękę podążają szlakiem przetartym przez wielkie państwowe przedsiębiorstwa ${ }^{22}$. Oficjalne chińskie statystyki są nie do końca wiarygodne również z innego względu. Wszystkie przedsiębiorstwa podejmujące inwestycje sa zobowiązane do przedstawienia odpowiednich informacji do lokalnego oddziału Ministerstwa Handlu (Ministry of Commerce - MOFCOM) za pośrednictwem systemu elektronicznego. Krajowe Biuro Statystyczne (The National Bureau of Statistics) podsumowuje następnie zgromadzone wcześniej dane. Teoretycznie raporty MOFCOM powinny śledzić przepływy BIZ, zliczając wszystkie inwestycje podjęte przez chińskie przedsiębiorstwa za granica. Występuja jednak znaczne uchybienia we wspomnianym systemie. Ponadto istnieje jeszcze jeden ważny aspekt potwierdzający ułomność obecnego systemu chińskie przedsiębiorstwa zgłaszają do oddziału Ministerstwa Handlu pierwszy, a nie ostateczny kierunek inwestycji. Z tego względu jako miejsce inwestycji podawane są raje podatkowe, w tym Kajmany oraz Brytyjskie Wyspy Dziewicze, choć ostatecznie inwestycje trafiają do innych krajów. Według danych MOFCOM ok. 80\% wszystkich BIZ skierowanych jest do Hongkongu lub wspomnianych rajów podatkowych ${ }^{23}$.

Pomimo że inwestycje w Afryce Subsaharyjskiej mają niewielki udział w globalnym przepływie kapitału, z punktu widzenia lokalnych gospodarek jego znaczenie rośnie i dotyczą coraz większej liczby sektorów. Wysokość udziału bezpośrednich inwestycji zagranicznych w PKB regionu jest porównywalna ze średnią dla innych grup krajów na świecie, co wynika przede wszystkim z niższej wysokości PKB krajów subsaharyjskich. Oznacza to jednocześnie, że nawet nieduże inwestycje (z punktu widzenia krajów wysoko rozwiniętych) stanowią istotny zastrzyk kapitału dla krajów afrykańskich, gdzie rodzimego kapitału nie ma zbyt wiele ${ }^{24}$.

\section{Motywy inwestycyjne chińskich przedsiębiorstw Afryce}

Śledząc badania motywów chińskich inwestycji bezpośrednich w Afryce, warto zwrócić uwagę na prace Stephena Gelba, który wykazał, że poszukiwanie rynku i poszukiwanie zasobów to czynniki determinujące inwestycje południe - południe $(\text { South }- \text { South })^{25}$. Z kolei Cheung i inni w analizie empirycznej zbadali determinanty

22 I. Yuan Sun, K. Jayaram, O. Kassiri, Dance of the lions and dragons. How are Africa and China engaging, and how will the partnership evolve?, McKinsey \& Company, June 2017, s. 2.

23 M. Młody, Uwarunkowania beapośrednich inwestycji zagranicznych Chinskiej Republiki Ludowej w Ameryce Łacinskiej w latach 1992-2012, rozprawa doktorska napisana pod kierunkiem prof. dr. hab. Henryka Mruka na Uniwersytecie Ekonomicznym w Poznaniu, Poznań 2014, s. 95.

${ }^{24}$ K. Świerczyńska, Uwarunkowania i zróżnicowanie rožwoju gospodarczego krajów Afryki Subsabaryjskiej, Warszawa 2019, s. 153.

25 S. Gelb, South-south investment: the case of Africa [w:] Africa in the World Economy: The National, Regional and International Challenges, eds. J.J. Teunissen, A. Akkerman, Hague 2005, s. 200-205. 
chińskich bezpośrednich inwestycji zagranicznych w Afryce i stwierdzili, że głównymi motywami chińskich inwestycji w Afryce sa: dążenie do nowego rynku, czynnik ryzyka (szczególnie politycznego) oraz poszukiwanie zasobów ${ }^{26}$. Autorzy wskazali również na silne znacznie intensywności wymiany handlowej. Podobne badanie przeprowadziła E. Asiedu ${ }^{27}$, która na podstawie panelu składającego się z 22 państw Afryki Subsaharyjskiej stwierdziła, że kraje wyposażone w zasoby naturalne lub mające duże rynki zbytu przyciągnęły więcej bezpośrednich inwestycji zagranicznych niż kraje ubogie w surowce mineralne. Ponadto wyniki jej badań wskazują, że dobra infrastruktura, wykształcone zasoby pracy, stabilność makroekonomiczna, otwartość na bezpośrednie inwestycje zagraniczne, wydajny system prawny, niski poziom korupcji i stabilność polityczna również przyciagają chińskie bezpośrednie inwestycje zagraniczne do krajów afrykańskich.

Zaangażowanie Chin w Afryce cechuje ścisły związek między handlem, inwestycjami i finansami. Prawie wszystkie kraje afrykańskie korzystaja z chińskich bezpośrednich inwestycji zagranicznych, które rozciagają się na cały kontynent i są coraz bardziej zróżnicowane. Chociaż ropa naftowa i wydobycie innych złóż metali nadal mają duży udział, usługi finansowe, budownictwo i produkcja stanowia obecnie ok. 50\% chińskich BIZ w Afryce. Chińskie banki wsparły inwestycje w infrastrukturę na kontynencie, a ponad 2200 chińskich firm, głównie prywatnych, działa obecnie w krajach afrykańskich. Chiński handel niewątpliwie przyczynił się do wzrostu gospodarczego w Afryce. Szczególnie eksporterzy towarów skorzystali z wysokiego popytu i związanych z tym podwyżek cen, a konkurencyjność zasobów naturalnych innych niż ropa naftowa wzrosła w ciagu ostatniej dekady. Gdy współpraca handlowa między Chinami i Afryką przechodzi do następnego etapu, istnieje duża możliwość dywersyfikacji eksportu, zwłaszcza rolnictwa. Opierając się na własnych doświadczeniach, Chiny mogłyby pomóc krajom afrykańskim w rozwiązaniu problemów strukturalnych i logistycznych ograniczających konkurencyjność tego eksportu ${ }^{28}$.

Chińskie bezpośrednie inwestycje zagraniczne w Afryce wzrosły w szybkim tempie od 2004 r., kiedy rząd Chin podjął wiele środków, aby zachęcić rodzime przedsiębiorstwa do inwestycji zagranicznych. Tendencja wzrostowa utrzymała się nawet podczas światowego kryzysu finansowego w 2008 r., kiedy to rządy wprowadziły również preferencyjne programy pożyczek. Inwestycje, zwłaszcza w sektory energetyczny i transportowy, pomogły rozwiązać problemy związane z infrastruktura techniczną, z którymi zmaga się wiele krajów afrykańskich. Podczas gdy inwestowa-

26 Y.W. Cheung, J. De Haan, X. Qian, S. Yu, China's outward direct investment in Africa, „Review of International Economy" 2012, vol. 20, issue 2, s. 201-220.

27 E. Asiedu, Foreign direct investment in Africa: the role of natural resources, market size, government policy, institutions and political instability, „,World Economy” 2006, vol. 1, s. 63-77.

28 M. Pigato, China and Africa: Expanding economic ties in and evolving global context, UNCTAD, Geneva 2015, s. 1. 
nie w Afryce zapewniło chińskim firmom nowe możliwości, kraje afrykańskie skorzystały z technologii i know-how przywiezionych przez chińskich przedsiębiorców, a także tworzyły wiele dodatkowych miejsc pracy. Niektóre centra produkcyjne sa zorientowane na eksport, wykorzystując bezcłowy wjazd do Chin, podczas gdy inne mają na celu zaopatrywanie rynków lokalnych i regionalnych. W miarę wzrostu chińskich inwestycji i coraz większej liczby przedsiębiorstw rozpoczynających działalność w krajach afrykańskich wyzwaniem dla lokalnych firm będzie pozostanie konkurencyjnym i wykorzystanie możliwości integracji z globalnymi łańcuchami wartości ${ }^{29}$.

Kraje afrykańskie mają wyjątkową okazję do przyciągnięcia strategicznych inwestycji tworzących miejsca pracy z Chin, a także innych partnerów, ale musza rozpocząć działania jak najszybciej. W niektórych przypadkach będzie to wymagać zmiany polityki i podjęcia wysiłków w celu przyciagnięcia inwestorów. Stworzenie sprzyjającego klimatu dla inwestycji zarówno z Chin, jak i innych krajów będzie wymagać wprowadzenia polityki wspierającej inwestycje. W jej ramach ważne będa takie działania, jak: obniżenie kosztów transportu i energii, eliminacja formalnych i nieformalnych barier w handlu, zwiększenie elastyczności rynków pracy oraz zapewnienie skutecznej polityki konkurencji. Pomoże to również afrykańskim firmom zwiększyć produktywność i konkurencyjnośćc ${ }^{30}$.

Inwestycje Chin w Afryce mogą wpływać na transformację gospodarczą i dywersyfikację eksportu. Aby tak się stało, zarówno kraje afrykańskie, jak i Chiny muszą zmaksymalizować wpływ swojego partnerstwa na rozwój. Pozytywne doświadczenia można wykorzystać, a kraje afrykańskie są zainteresowane czerpaniem z doświadczeń Chin w zakresie generowania wzrostu i ograniczania ubóstwa. Konieczne jest proaktywne podejście ze strony rządów afrykańskich oraz prywatnych firm. Poprawa klimatu biznesowego może przyciąnnąć więcej dużych chińskich przedsiębiorstw do inwestowania w Afryce, zapewniając im dostęp do technologii, know-how i szkoleń oraz transfer wiedzy, a także powiązania z globalnymi łańcuchami dostaw. Partnerstwa między chińskimi i afrykańskimi firmami, poprzez wspólne przedsięwzięcia oraz powiązania wyższego i niższego szczebla, pomogłyby rozwinaćć sektor prywatny w krajach afrykańskich, stwarzając możliwości wzrostu zatrudnienia.

Warto też wziąć pod uwagę ewentualne negatywne skutki chińskich BIZ w Afryce. Mark Klaver i Michael Trebilcock postawili pytanie badawcze, czy chińskie zaangażowanie na kontynencie afrykańskim jest dobre, czy złe dla samej Afryki. Autorzy ci wskazują na siedem czynników, które mogą sprawić, że chińskie inwestycje przyczynią się do rozwoju gospodarczego krajów afrykańskich. Sa to: ceny towarów (popyt Chin na zasoby podniósł ceny towarów), zdolność wydobycia (wiele krajów afrykańskich nie ma możliwości wydobycia własnych zasobów), infrastruktura (wkład Chin w rozwój Afryki jest prawdopodobnie

29 Ibidem.

30 Ibidem, s. 2 . 
najbardziej znaczący w infrastrukturze), produkcja (chińskie inwestycje mogą rozwinąc afrykański sektor produkcyjny), zatrudnienie (chińskie inwestycje tworza miejsca pracy), dostęp do rynku (Chiny poprawiają dostęp Afryki do swojego rynku poprzez obniżenie chińskich taryf), a także konsumenci (chińskie BIZ przynoszą korzyści afrykańskim konsumentom poprzez obniżenie cen wytwarzanych towarów i żywności). Zaznaczają oni jednak, że chińskie bezpośrednie inwestycje zagraniczne mogą mieć niewielki wpływ na rozwój technologiczny, wzrost umiejętności u pracowników oraz wzrost zatrudnienia ${ }^{31}$. Natomiast O. Ademola, A. Bankole i A. Adewuyi stwierdzili nawet, że negatywne skutki mogą przeważać nad pozytywnymi w wielu krajach afrykańskich ${ }^{32}$.

\section{Podsumowanie}

Od początku XXI wieku odnotowuje się gwałtowny rozwój wymiany handlowej na linii Chiny - Afryka i chińskich bezpośrednich inwestycji zagranicznych w krajach afrykańskich. Ponieważ dynamicznie rozwijająca się już od kilku dziesięcioleci chińska gospodarka potrzebuje olbrzymiej ilości surowców, naturalne jest duże zainteresowanie Chin krajami afrykańskimi jako potencjalnym ich źródłem. Skala inwestycji i wymiany handlowej w XXI wieku sprawia, że Chiny stają się nową siłą wpływająca na rozwój gospodarczy kontynentu. Ich aktywność w Afryce szczególnie mocno objawia się w części subsaharyjskiej - bogatej w surowce, gdzie Chiny wykorzystuja nieobecność zachodnich koncernów. Dla Państwa Środka afrykańskie surowce i inwestycje w sektorze energetycznym są ważnym elementem, od którego uzależniony jest dalszy rozwój gospodarczy kraju, ale rośnie też udział chińskich BIZ w innych sektorach, takich jak budownictwo czy usługi finansowe. To prowadzi do wniosku, że chociaż bezpieczeństwo zasobów jest ważną kwestią dla Chin, podejście Pekinu do Afryki wydaje się znacznie szersze, niż się powszechnie uważa. Afryka jest rozwijającym się rynkiem i zapewnia chińskim firmom większe możliwości zdobywania doświadczenia nie tylko w zakresie wydobycia surowców, ale także w innych segmentach rynku. Nie do przecenienia jest afrykański potencjał rolny, który można wykorzystać w celu poprawy bezpieczeństwa żywnościowego. Jeżeli jakiś czynnik jest w stanie w sposób strukturalny zagrozić stosunkom inwestycyjnym Chiny Afryka, to jest nim spowolnienie gospodarcze, które może ograniczyć popyt na surowce i powstrzyma odpływ kapitału z Chin.

31 M. Klaver, M. Trebilcock, Chinese Investment in Africa, „Law and Development Review” 2011, vol. 4 , issue 1 , s. $168-217$.

32 O. Ademola, A. Bankole, A. Adewuyi, China-Africa trade relations: insight from AERC scoping studies, „European Journal of Development Research” 2009, vol. 21, issue 4, s. 485-505. 


\section{SUMMARY}

\section{TERMS AND CONDITIONS \\ OF CHINESE FOREIGN DIRECT INVESTMENT IN AFRICA}

China's growing involvement in sub-Saharan Africa continues to attract interest from researchers and the public. The purpose of this article is to present the motives and conditions of Chinese foreign direct investment in Africa in relation to the most important theories of FDI placement. It has been hypothesized that the main motive of Chinese FDI in Africa is the search for resources. Descriptive, analytical and literature studies were used in the research work. As a conclusion, it appears that China's activity in Africa is particularly strongly manifested in the sub-Saharan part - rich in raw materials, where China takes advantage of the absence of Western concerns. For China, African raw materials and investments in the energy sector are important elements on which the country's further economic development depends, but the share of Chinese FDI in other sectors such as construction and financial services is also growing. This leads to the conclusion that although security of resources is an important issue for China, Beijing's approach to Africa seems to be much broader than is commonly thought. Africa is a growing market and provides Chinese companies with greater opportunities to gain experience not only in the field of raw material extraction, but also in other market segments. Africa also has agricultural potential that can be used to improve food security. 